\title{
Structural Adjustment, Labour and the Poor in Pakistan
}

\author{
Shahrukh Rafi Khan* and Safiya Aftab
}

\begin{abstract}
In this paper we cite evidence regarding the likely impact of IMF/World Bank policies on labour and the poor in Pakistan. Our findings show that since the 1987 bout of structural adjustment, public sector employment has decreased while wages have been frozen. Also, overall unemployment in occupations with a high incidence of the poor has dramatically increased and real wages of skilled and unskilled labour sharply declined. In addition, subsidies that were critical to the consumption pattern of the poor have been cut while the burden of indirect taxes on the poorest income group has increased. Not surprisingly, there has been an increase in poverty and inequality, particularly in the rural areas.
\end{abstract}

\section{Introduction}

In his much cited article, Huntington stated "Through the IMF and other international economic institutions, the West promotes its economic interests and imposes on other nations, the economic policies it thinks appropriate." Such statements are enough to make even the most level headed Third World thinkers paranoid. Cross country evidence has not conclusively demonstrated that countries that have tried to reform their economies according to IMF/World Bank inspired structural adjustment prescriptions (in exchange for loans) have succeeded. There are some success stories and many failures. Establishing success empirically is difficult since often counter-factuals are needed but not available i.e. what would have been the condition of the country without structural adjustment? Even when enough time has passed to assess reforms, it is difficult to isolate the impact of structural reforms from everything else going on in the economy. Failures stare one in the face in the form of riots that have so frequently followed structural adjustment programmes in the Third World.

From the perspective of the Bretton Woods Institutions, failure can be defined by looking at a country's performance indicators, such as the growth rate, or in terms of meeting specific performance indicators identified as conditionalities for specific loans. In fact, from the Fund/Bank point of view the two could be regarded as synonymous since the conditionalities are viewed

\footnotetext{
${ }^{*}$ Sustainable Development Policy Institute.

${ }^{1}$ Huntington (1993) pp. 39.
} 
as necessary for robust economic growth. Broader social indicators such as the Human Development Indicators are clearly relevant in judging performance but, until recently, have been viewed as secondary. Some may argue that such indicators are only being paid lip-service to, although this point would also need to be established empirically.

Why do industrialised countries push structural adjustment? Perhaps they want to see poor countries shaped in their own image. The best motive to ascribe to them is that they are persuaded by the evidence that this is in the interest of the economies they lend to. As prudent bankers, the IMF and the World Bank worry about repayments. However, there is a distinction between the short and long run interests of the country. For example, a devaluation may improve the balance of payments in the short-run and avoid default, but does it help in the long run? This is really an empirical issue and the answer is likely to differ for each country. Among other things, the outcome depends on the relative demand and supply elasticities of our imports and exports. Meanwhile production costs do go up due to more expensive imports in rupee terms and this could lead to higher inflation. Higher costs of production could also hurt future exports. On the other hand, a devaluation is definitely in the interest of industrialised country trading partners, since they have access to cheaper raw materials. Foreign investors benefit as hard currencies now go further. The recommendation of currency convertibility to encourage foreign investment allows easy profit repatriation. But currency convertibility can bring with it destabilising capital movements and encourage capital flight. ${ }^{2}$ Debtor countries also tend to lose from a devaluation as the local currency value of the foreign debt (which is denominated in dollars) increases substantially.

There is no question that LDCs need access to foreign technologies, marketing and managerial skills. But the price could be that of wiping out domestic industry. If industries lack competition, foreign investment may be one welcome antidote. If that is not the issue, a hard nosed and selective attitude towards foreign investment may be warranted. Once again, there is no substitute for a case by case empirical examination if a reasonably honest administrative capacity exists. If it does not, many have rightly recognised that to be first on the reform agenda.

The main point in this paper is that, in as much as it is possible, evidence rather than rhetoric should be guiding national policy with regard to structural reform. Those reforms which are in the national interest should be

\footnotetext{
${ }^{2}$ This in fact happened in a number of Latin American economies including Chile and Argentina in the early eighties and again recently in mexico and other Latin American and Asian countries.
} 
implemented anyway. However, until LDCs get their fiscal house in order, they can use these reforms as leverage for loans. Those not in the national interest should be resisted. A solid foundation of empirical evidence would help in the negotiation process. This paper draws together some of the important evidence with regard to the impact of structural adjustment on the poor and identifies other areas where much research needs to be done.

There is an important qualification to what was stated in the paragraph above. On many issues, it is not at all clear what the national interest means. In fact, since structural reforms usually have a differential impact on different social classes, one invariably needs to go beyond thinking in broad categories such as the national interest. The conceptual framework needs to have two components. First, the assessment of reforms by social class and second, whether society would be better off with the reform once the gainers compensate the losers. ${ }^{3}$

The paper starts with an overview of structural adjustment agreements in Pakistan. The likely impact on labour and the poor are discussed next on a conceptual level. We present evidence of the likely impact of structural adjustment on labour and the poor in the forth section and end with certain concluding remarks.

\section{Overview of structural adjustment agreements in Pakistan}

Pakistan's first agreement with the IMF dates back to 1958. This was a standby loan for SDR 25 million, but it was not utilised. Since the first plea to the IMF for assistance in $1978-79$ by the Zia regime, some form of conditionality in return for loans has become a permanent feature in the economic landscape of the country. ${ }^{4}$ In this brief section we focus on conditionalities that are likely to have a direct or indirect impact on labour or the poor.

The Zia-ul-Haq regime began the process of liberalisation. However, after Zia's death, towards the end of the 1987-88 fiscal year when elections were pending, the more concerted period of adjustment began. A surge in imports, coup0led with a sharp reduction in worker's remittances served to drive the current account deficit up to 4.4 per cent of the GDP. The budget deficit in the same year shot to a record level of 8.5 per cent of the GDP.'

\footnotetext{
${ }^{3}$ This latter is of course the standard Pareto condition applied to social classes rather than individuals.

${ }^{4}$ The following description of structural adjustment agreements is partly based on sections of chapter 5 of Just Adjustment eds. Banuri, Khan and Mahmood (1997).

${ }^{5}$ Economic Survey 1995-96, Statistical Appendix (1996, p. 138, p. 160).
} 
The government was not equipped to deal with these persistent macroeconomic imbalances and began to negotiate with the IMF and the World Bank for the disbursement of a series of loans under the Structural Adjustment Facility. ${ }^{6}$ It signed a three-year agreement with the IMF for a structural adjustment facility of $\$ 2.1$ billion. This was to be accompanied by a package of structural reforms.

The first Structural Adjustment Facility was ratified and signed on December 28, 1988 by the first Benazir Bhutto government, which besides other conditionalities, called for a substantial reduction in the budgetary deficit from 8.5 to 4.8 per cent of GDP over the 1988-89 to 1990-91 period. To meet these objectives the revenue-GDP ratio was raised to 20 per cent by 1990-91 through a series of measures which included the extension of General Sales Tax to cover at least 30 per cent of domestic industrial production, and reforms in the tax collection and assessment systems. The expenditure-GDP ratio was to be contained to less than 25 per cent of the GDP, largely through reductions in cash and economic subsidies. The conditionalities also included ensuring controls on inflation and credit expansion and instituting a series of financial and exchange rate reforms. The resource mobilisation measures proposed by the Programme included the introduction of a generalised system of sales taxes, withdrawal of exemptions from custom duties, imposition of user charges and improvement in tax administration.

The government responded to these conditionalities immediately and did institute a series of reforms, but they remained largely unsuccessful in achieving the performance criteria set by the donor agencies. The government subsequently re-negotiated these terms to delay adjustment by an extra year.

The objectives of the 1991-1994 structural adjustment programme were set down in a memorandum at the time of the agreement. The broad objectives to be achieved over a three year period, largely remained consistent with the earlier agreement. They were an annual growth rate of GDP of at least 5.5 per cent of GDP, increase in foreign exchange reserves to at least 4 weeks of imports, decrease in the external debt ratio from 31 to 25 per cent of GDP, decrease in fiscal deficit eventually from 8.5 to 4.5 per cent of GDP, increase in domestic savings from 9 to 10 per cent of

${ }^{6}$ SAF loans are designed to address immediate balance of payments (BOP) crises. They may provide general import financing or may be used to finance the import needs of a particular sector. Although the loans are almost always meant to correct BOP payments difficulties, there is a string of conditionalities attached to them which relate to all sectors of the economy and are aimed at bringing about fundamental changes in the macroeconomic structure of the economy. 
GDP, increase in gross investment from 16 to 19 per cent of GDP, reduction in domestic borrowing for budgetary support to 4 per cent of GDP, bank borrowing of no more than 1 per cent of GDP, decreased reliance on taxes on international trade, especially import duties and an expansion of the tax base.

In August 1993, the interim government set about negotiating a stand-by agreement with the Bank and the Fund, and announced a set of economic reforms that essentially set the guidelines for the economic policies of the next government. In December 1993, the newly elected government formalised the agreement with these agencies by submitting a request for another three year Structural Adjustment Facility loan equal to the amount of SDR 606.6 million. $^{7}$ The proposal was approved in February 1994 , and carried with it an even more stringent set of conditionalities. This time the emphasis was on trade reforms including the elimination of multiple exchange rate practices, full convertibility of the rupee and stringent tariff reduction over a three year period. Taxation reforms that were suggested included the extension of the general sales tax to cover almost all items on the free list and all businesses in the trading and services sectors as well as the imposition of further excise duties on utilities. However, the situation in 1994-95 was more difficult than that in 1988-89. The Gulf war led to a drop in remittances from overseas Pakistanis to \$1.4 billion, while the disruption of trade with Middle Eastern countries jacked up the total loss in foreign exchange earnings for this reason to approximately $\$ 2$ billion. In addition, political differences led to the winding up and termination of bilateral aid from the USA which made the generation of additional revenues more necessary.

The performance criteria of the $1994 \mathrm{EFF} / \mathrm{ESAF}$ agreement required the budget deficit to be restricted to 4 per cent of GDP, inflation contained to 7 per cent and the highest import tariff reduced to 70 per cent in 199495,45 per cent in 1995-96 and 35 per cent in 1996-97. However, due to political compulsions and adverse financial considerations, described in the paragraph above, in framing the 1994-95 budget, Pakistan reneged on the revenue and tariff targets. This led to the angry cancellation by the IMF of the Structural Adjustment Facility. The Government of Pakistan then IMF of the Structural contrite, made all the proper noises about keeping within specified targets and hoped for a resumption of the Structural Adjustment Facility (SAF). While a SAF was not granted by the IMF, a standby loan of $\$ 600$ million for balance of payments support was agreed to.

\footnotetext{
${ }^{7}$ This was the biggest ever loan request received by the Fund under the Saf according to Dawn (Jan 21, 1994).
} 


\section{Some conceptual issues}

Should the poor worry about structural adjustment? The answer is probably yes, although again this is an empirical issue. As mentioned above, one of the more stringent conditionalities of the SAF loans is that the government should reduce the budget deficit through suitable demand management policies and by specific reforms aimed at cutting expenditures and increasing revenues. Curtailing expenditure invariably translates into cuts in subsidies and in expenditure on social sectors, measures which are easier to undertake than, say, a substantial reduction in defence spending.

But these expenditure cuts are likely to adversely affect the poorer sections of society, as do wage restraints and increases in utility charges, which are also recommended by the Bank and the Fund. The imposition of a comprehensive General Sales Tax and the subsequent inflation will also hurt the poor more. Structural adjustment programmes also tend to be followed by widespread unemployment. In a country such as Pakistan, where the government is the largest employer, a reduction in government expenditure immediately translates into a freeze on recruitment in government offices. ${ }^{8}$ The imposition of greater taxes on the business community also tends to lead to large scale laying off of industrial workers, as does privatisation. Inflation, the withdrawal of subsidies and, consequently, higher food prices in urban areas and greater unemployment are all part and parcel of adjustment programmes. It is not surprising that social unrest, and in many cases rioting, tends to follow intensive adjustment programmes.

Is the assumption about excessive and wasteful state expenditure warranted? Sometimes, but not always. Once again this is an empirical issue. It could be that inadequate physical and social infrastructure is resulting in a shortfall in production. In this case the answer would be to focus primarily on enhancing production rather than paring down expenditure.

In the next section we report evidence on the changed socioeconomic conditions of labour and the poor over the recent structural adjustment period. It would be naive to assume that structural adjustment "caused" these changes. Nonetheless, it is important to note how conditions have worsened and the burden of proof that this is not due to structural adjustment is on those who espouse it.

\footnotetext{
8 There has been a ban on recruitment in government offices in Pakistan since June 1990. This has been lifted for short periods from time to time, but has always been reimposed and is still in effect.
} 


\section{Some evidence from Pakistan}

Since the onset of the medium-term structural adjustment programme in 1987-88, the socio-economic conditions of labour and the poor seem to have deteriorated. While it is not possible in all cases to view structural adjustment as a "cause", in many cases there does appear to be a direct association. We start by reviewing the overall household economic progress by income group.

Table-1: Household monthly income and the percentage distribution of households by income groups ${ }^{9}$

\begin{tabular}{crr}
\hline Income Groups & Household monthly income in real terms \\
\cline { 2 - 3 } & $\mathbf{1 9 8 7 - 8 8}$ & $\mathbf{1 9 9 2 - 9 3}$ \\
\hline I & 634.49 & 282.93 \\
II & 1084.15 & 629.15 \\
III & 1744.13 & 1030.58 \\
IV & 2742.23 & 1572.77 \\
V & 5250.64 & 3326.60 \\
\hline
\end{tabular}

Source: Calculated from Household Income and Expenditure Survey, 1987-88 (1990, p. 183). Household Integrated Economic survey 1992-93 (1996, p. 254).

Notes: The income groups across the two years respectively represent $8.9,36.7,20.5,23.4,10.5$ per cent and 9.5, 31.9, 23.1, 22.1, and 13.4 per cent of the population.

As shown in Table-1 above, real income in all income groups declined over the period under study. The magnitude of the decline is highest for the lowest income group (56 per cent) and lowest for the highest income group ( 37 per cent). The Federal Bureau of Statistics gives inflation adjusted classifications of what income levels constitute low, middle and high income households in various years. The table above was calculated using the income categories defined in the Household Integrated Expenditure Survey 1987-88. This ensured that the data would be comparable over the period under study.

\footnotetext{
9 The consumer price index drawn from the Economic Survey 1995-96, Statistical
} Appendix (1996, p. 137) was used to deflate 1992-93 nominal values to a 1987-88 base. 
The income distribution evident from households sample survey data is typically compressed. This is because the poorest in the lowest income group, that do not even have fixed dwellings or reside in Kachi Abadies (shanty towns), get excluded. Such exclusion is also the case for the very rich since a mean real monthly income of about Rs. 5,000/- (\$192) for the upper income bracket for 1992-93 is unrealistically low. This also explains the apparent contradiction of a recorded increase in real per capita income during a period for which our results show mean household real income falling across the board for all income groups. It appears that all the recorded increase in per capita income for the country is accounted for by the increase in the income of the super rich.

Although structural adjustment may not be a cause of observed changes in standards of living, yet it is not possible to rule out an association. This is particularly the case with regard to employment and wages in the public sector. Responding to calls for fiscal discipline, the government pared down the work force and, until recently, froze wages as is evident from Table-2 below.

Table-2: Share of public sector employment cost in public expenditure and GDP

\begin{tabular}{ccc}
\hline & \multicolumn{2}{c}{ Share of public sector employment cost in } \\
\cline { 2 - 3 } Years & Public expenditure & GDP \\
\hline $1988-89$ & 35.3 & 7.9 \\
$1989-90$ & 34.5 & 7.5 \\
$1990-91$ & 32.3 & 7.0 \\
$1991-92$ & 30.6 & 6.7 \\
$1992-93$ & 28.7 & 5.9 \\
\hline
\end{tabular}

Source: $\quad$ Adopted from Kemal (1994, p. 8).

There is a steady decline in the public sector employment cost which coincides with the 1987-88 medium term structural adjustment period. This resulted from freezing nominal wages of government employees, bans on recruitment and the encouragement of early retirements via golden handshakes. ${ }^{10}$ While reducing the size of the public sector per se may not be injurious, expecting the labour market to

${ }^{10}$ Bilquese (1992, pp. 4-5) shows that for most public sector employees, "there was a massive erosion (in real wages) in the late eighties.” 
somehow absorb larger numbers is unrealistic. This is evident even from the much doubled official unemployment statistics as reported in Table-3 below. ${ }^{11}$

Table-1: Unemployment rates by occupational categories in Pakistan

\begin{tabular}{lccc}
\hline \multicolumn{1}{c}{ Occupational Groups } & $\mathbf{1 9 8 7 - 8 8}$ & $\mathbf{1 9 9 0 - 9 1}$ & $\mathbf{1 9 9 3 - 9 4}$ \\
\hline Professional and Technical & 5.3 & 6.7 & 6.1 \\
Administrative and Managerial & n.a. & 15.9 & 9.8 \\
Clerical and Related & 3.2 & 15.1 & 13.5 \\
Sales & 3.2 & 2.6 & 3.7 \\
Services & 3.2 & 9.6 & 8.3 \\
Agricultural & 0.9 & 1.9 & 1.0 \\
Production and Related Services & 7.1 & 13.3 & 10.5 \\
\hline
\end{tabular}

Source: $\quad$ Calculated from various Labour Force Surveys, 1987-88 (1989, p. 232), 1990-91 (1993, p. 335$)$ and 1993-94 (1994, p. 421).

One would expect a concentration of the poor in the clerical, sales, services, agricultural, production and related categories. In all these, the unemployment rate has risen dramatically between 1987-88 and 1990-91. ${ }^{12}$ However, in most cases, unemployment in 1993-94 was lower than in 1990-91, although still much higher than 1987-88. More spot observations over time are needed to see if this represents a continuing trend.

In addition to a decline in unemployment, real wages for skilled and unskilled labour over this period also declined dramatically as reported below in Table-4.

\footnotetext{
11 Part of the increase in unemployment rates represent a concession by the Federal Bureau of Statistics that they had been under-stating the unemployment rates in the past. Even so, the increase in unemployment rates are dramatic.

12 Chaudhry and Chaudhry (1992, pp. 6-8) in a more detailed study of the agricultural sector show that growth in employment opportunities in the 1984-85 to 1989-90 period at 0.65 per cent came to a virtual standstill compared to earlier periods. They attribute this to a fall in agricultural profitability due to the elimination of input subsidies.
} 
Table-4: Nominal daily wage of skilled and unskilled workers deflated by the food price index $(1980-81=100)$

\begin{tabular}{|c|c|c|c|c|}
\hline \multirow[t]{2}{*}{ Year } & \multicolumn{2}{|c|}{$\begin{array}{c}\text { Unskilled workers } \\
\text { (labourer) }\end{array}$} & \multicolumn{2}{|c|}{$\begin{array}{c}\text { Skilled workers } \\
\text { (mason) }\end{array}$} \\
\hline & $\begin{array}{c}\text { Peshawar } \\
\text { (lowest) }\end{array}$ & $\begin{array}{l}\text { Karachi } \\
\text { (highest) }\end{array}$ & $\begin{array}{c}\text { Peshawar } \\
\text { (lowest) }\end{array}$ & $\begin{array}{l}\text { Karachi } \\
\text { (highest) }\end{array}$ \\
\hline $1980-81$ & 18.00 & 27.5 & 60.0 & 65.0 \\
\hline $1981-82$ & 19.3 & 24.7 & 60.6 & 67.4 \\
\hline $1982-83$ & 18.7 & 25.4 & 62.6 & 67.0 \\
\hline $1983-84$ & 20.0 & 23.6 & 63.9 & 63.5 \\
\hline $1984-85$ & 18.4 & 22.6 & 53.9 & 58.5 \\
\hline $1985-86$ & 17.8 & 28.2 & 55.3 & 57.1 \\
\hline $1986-87$ & 20.4 & 27.3 & 51.1 & 61.4 \\
\hline \{Period & $(+13.3)$ & $(-0.7)$ & $(-16.5)$ & $(-7.0)$ \\
\hline \multicolumn{5}{|c|}{ Change (\%) $(1980-81 / 1986-87)\}$} \\
\hline $1987-88$ & 17.2 & 31.0 & 48.8 & 63.6 \\
\hline 1988-89 & 18.5 & 30.6 & 44.8 & 67.0 \\
\hline $1989-90$ & 20.0 & 30.1 & 48.0 & 63.8 \\
\hline $1990-91$ & 18.3 & 27.9 & 48.9 & 59.6 \\
\hline $1991-92$ & 21.0 & 26.2 & 40.1 & 58.2 \\
\hline $1992-93$ & 20.0 & 26.1 & 40.4 & 60.2 \\
\hline $1993-94$ & 17.6 & 25.8 & 40.0 & 56.9 \\
\hline 1994-95 & 17.8 & 23.3 & 40.0 & 51.4 \\
\hline$\{$ Period & $(+0.8)$ & $(-24.8)$ & $(-18.0)$ & $(-19.2)$ \\
\hline Change & $3-95)\}$ & & & \\
\hline
\end{tabular}

Source: Economic Survey, 1995-96, Statistical Appendix, (1996), pp. 25-26 for nominal wages and p. 146 for the food price index.

Notes: Peshawar and Karachi were selected as the two major cities with the lowest and highest daily wages in the base period.

For unskilled workers, there is a convergence of wages in Peshawar where they were the lowest with those in Karachi where they were the highest. This is to be expected as migration south to Karachi could be expected to gradually cause the wages in the northern urban centers to rise. However, real wages for unskilled workers in Karachi dclined by about one 
per cent in the $1980-81$ to $1986-87$ period and about 25 per cent in the 1987-88 to $1994-95$ period.

The decline in real wages for skilled workers occurred in both cities and in both periods, although more in the later period. Between 1980-81 and 1986-87 real wages for masons declined by 16.5 per cent and 7.0 per cent while during the 1987-88 to $1994-95$ period they declined by 18.0 and 19.2 per cent in Peshawar and Karachi respectively.

One would also expect increasing unemployment and a decline in real wages to be accompanied by increasing inequality and poverty. This is indeed the case as is evident from Table- 5 below.

Table-5: Inequality and absolute poverty in Pakistan

\begin{tabular}{cccccccc}
\hline & \multicolumn{3}{c}{ Overall } & \multicolumn{2}{c}{ Rural } & \multicolumn{2}{c}{ Urban } \\
\cline { 2 - 8 } & $\begin{array}{c}\text { Income } \\
\text { share ratios }\end{array}$ & Gini & Poverty & Gini & Poverty & Gini & Poverty \\
\hline $1984-85$ & 6.2 & .43 & 18.3 & .35 & 21.1 & .38 & 11.1 \\
$1987-88$ & 5.5 & .35 & 16.6 & .31 & 19.6 & .37 & 8.7 \\
$1990-91$ & 6.1 & .41 & 17.2 & .41 & 20.6 & .39 & 9.8 \\
\hline
\end{tabular}

Source: Adopted from Malik et. al. (Table II.1 and II.5). Recent estimates in Gazdar (1994) based on the 1991 Pakistan Integrated Household Survey (PIHS) are much higher..

As Table-5 above shows, inequality as reflected by income share ratios and gini coefficients, has increased as has absolute poverty. Income share ratios represent the ratios of the income share of the richest twenty per cent of the households divided by the income share of the bottom twenty per cent. The numbers show an equalisation trend in the mid to late eighties that was reversed in the early nineties. The same story is evident from the gini coefficients. The urban-rural disaggregation shows the sharp rise in inequality in the rural areas relative to the urban areas.

The poverty numbers are based on a head count of the percentage of the population below a calorie based poverty line. Not surprisingly, the numbers reflect the pattern evident from measures of inequality. There is the same pattern of decline in absolute poverty from the mid to the late eighties and then a rise in the early nineties. Second, poverty is strikingly more a rural than an urban phenomenon and has become more so over time. Another study by Malik on nutrition (1992), based on data from the 
National Nutrition Survey of 1985-87 and the Demographic and Health Survey 1990-91 shows that there has been an improvement in nutritional status over time for children below the age of two years. However, this trend has been reversed for the age group of four to five years. In any case, the prevalence of chronic and severe malnutrition is high in the country by all accounts.

Unemployment could account for much of the increase in inequality and in poverty, although this issue needs further exploration. Given the consumption pattern of the poor and the incidence of taxes and subsidies which prevailed prior to the recent structural adjustment measures, one could have anticipated the increase in poverty and can certainly explain it with hindsight. We first look at how spending on subsidies and social services have fared as a percent of total expenditures. We have also included expenditures on defense and interest payments in Table-6 below.

Table-6: Proportion of total government spending on subsidies, Social sectors, interest payments and defense

\begin{tabular}{lcccc}
\hline Year & $\begin{array}{c}\text { Current } \\
\text { Subsidies }\end{array}$ & $\begin{array}{c}\text { Social } \\
\text { Services }\end{array}$ & Interest & Defense \\
\hline $1987-88$ & 4.4 & 9.6 & 18.4 & 26.1 \\
$1988-89$ & 6.6 & 9.6 & 18.9 & 25.4 \\
$1989-90$ & 4.1 & 9.1 & 21.1 & 26.5 \\
$1990-91$ & 4.1 & 10.8 & 19.2 & 24.8 \\
$1991-92$ & 2.5 & 14.1 & 19.4 & 23.6 \\
$1992-93$ & 2.1 & 15.7 & 22.6 & 25.0 \\
$1993-94$ & 1.4 & 15.5 & 24.9 & 25.2 \\
$1994-95$ (RE) & 1.5 & 16.5 & 23.8 & 23.4 \\
\hline
\end{tabular}

Source: Economic Survey, 1995-96, Statistical Appendix, (1996), p. 140).

Notes: $\quad \mathrm{RE}=$ Revised Estimate.

It is of interest that defence expenditures have been contained and that interest payments continue to expand. Our focus here is on social services and subsidies. Expenditures on social services have steadily increased and it therefore seems that there is more than lip service concerning the increase in focus on the social sectors. There is an implicit subsidy involved in social sector expenditures since the government is not recovering all such expenditures in user charges. Education is an important component of social 
services, and given the major shift during the Seventh Plan away from expenditures on higher education and towards primary education, the rural poor are so far the recipients of this subsidy. ${ }^{13}$ These subsidies in education and public health may be reduced to some extent if user charges are imposed. Also, the combined expenditure on education and health as a percentage of GDP remained virtually unchanged between 1987-88 and $1995-96 .{ }^{14}$

The picture with regard to the steady decrease in subsidies is not so sanguine. As the table below indicates, the bulk of the subsidies were on wheat, sugar and edible oil which are an important component of the total consumption basket of the poor.

Table-7: Subsidies on wheat, sugar and edible oil as a percentage of current subsidies

\begin{tabular}{lcc}
\hline Year & $\begin{array}{c}\text { Subsidies on wheat } \\
\text { and sugar }\end{array}$ & Subsidies on edible oil \\
\hline $1987-88$ & 49.3 & - \\
$1988-89$ & 54.9 & 21.4 \\
$1989-90$ & 50.0 & - \\
$1990-91$ & 43.3 & 21.1 \\
$1991-92$ & 51.0 & 2.0 \\
$1992-93$ & 52.7 & - \\
$1993-94$ & 70.4 & 9.0 \\
$1994-95$ (RE) & 53.2 & 12.5 \\
\hline
\end{tabular}

Source: Pakistan Economic Survey, 1995-96, p. 141).

Notes: $\quad \mathrm{RE}=$ Revised Estimate.

The table above shows that not only have total subsidies declined but the share of wheat, sugar and edible oil in these subsidies have also declined sharply. The decline in subsidy accompanied an increase in the support price of wheat which rose from Rs. 64 per $40 \mathrm{~kg}$ in 1983-84 to Rs. 173 per $40 \mathrm{~kg}$ in 1995-96, an increase of one hundred and seventy per cent. Between 1984 and 1994, nominal wages for unskilled labour in Karachi increased one

\footnotetext{
${ }^{13}$ Education expenditures by plan period are cited in Table-3 of the SPDI Citizen's Report (1996), chapter on education.

${ }^{14}$ Pakistan Economic Survey 1995-96, Statistical Appendix, (1996, p. 7).
} 
hundred and fifty-seven per cent. ${ }^{15}$ The increase in wheat price is of concern since the lowest income group derive 70 per cent of their potein and 55 per cent of their calories from this source. ${ }^{16}$ Also of concern is the changing share of wheat in the consumption basket of the lowest income group as reported in the Table below.

Table-8: Expenditure on wheat and fuel as a proportion of total household expenditure

\begin{tabular}{crrrr}
\hline Income Groups & \multicolumn{2}{c}{ Wheat } & \multicolumn{2}{c}{ Fuel } \\
\cline { 2 - 5 } & $\mathbf{1 9 8 7 - 8 8}$ & $\mathbf{1 9 9 2 - 9 3}$ & $\mathbf{1 9 8 7 - 8 8}$ & $\mathbf{1 9 9 2 - 9 3}$ \\
\hline I & 12.07 & 24.71 & 7.76 & 17.65 \\
II & 10.82 & 13.34 & 7.06 & 10.16 \\
III & 9.21 & 10.19 & 6.19 & 7.67 \\
IV & 7.34 & 7.97 & 5.57 & 6.38 \\
V & 6.02 & 4.15 & 4.49 & 3.89 \\
\hline
\end{tabular}

Source: Calculated from Household Income and Expenditure Survey, 1987-88 (1989, pp. 183, 233, 263) and Household Integrated Economic survey 1992-93 (1996, pp. 254, 287, 322).

Notes: $\quad$ As in Table-2.

As is shown in Table- 8 above, expenditure on wheat increased sharply for low and middle income households. This is contrary to past trends and expectations and could be accounted for by a substitution away from other foods. Ender, Wasay and Mahmood (1992, p. 1164) show a declining trend in the consumption of wheat in the past for the lowest income quartile and argue that this is expected with a rise in prosperity.

Looking at the consumption pattern of the poor shows that they have been hurt many times over. Not only have they borne a disproportionate burden of the cuts in employment, cuts in employment, cuts in subsidies and the rise in prices, but they have also started bearing more of the tax burden. Using consumption patterns, Kemal and Mahmood (Just Development, Chapter 4) showed that the burden of taxes on the poor increased by 10.3 per cent while that on the richest group declined by 4.3 per cent between 198788. Taking only the poorest and richest income categories into account, the indirect tax structure remained mildly progressive with the poor paying 7.8

\footnotetext{
${ }^{15}$ Pakistan Economic Survey 1995-96, Statistical Appendix, (1996, pp. 26, 60).

${ }^{16}$ Khan, Kazmi and Ahmed (1996, Table-2).
} 
per cent of their income in taxes and the richest 11.0 per cent in 1990-91. During this period, the share of indirect taxes in total taxes also declined from 87 per cent of total taxes to 84 per cent and it has declined further to 72 per cent by $1995-96 .{ }^{17}$ However, a simple decline in indirect taxes as a percentage of the total is not enough. The real issue is how sensitive the indirect tax structure (now referred to as the Generalised Sales Tax) is to the consumption pattern of the poor (via exemptions) and how this subsequently affects their tax-burden.

\section{Concluding remarks}

Our approach to structural adjustment is not an ideological one. We believe that some sensible policies may be recommended as part of the structural adjustment package and one needs to keep the national interest in mind when assessing structural reform. However, it may not always be helpful to think on such a broad level, since the impact of structural adjustment is likely to differ a great deal by income group. This paper focuses primarily on the impact of the post 1987-88 bouts of structural adjustment policies on labour and the poor.

The evidence to date is less than heartening. Owing to privatisation, golden handshakes, and an employment and wage freeze, the share of public sector employment cost in total public sector employment decreased from 35.3 to 28.7 per cent. In the presence of excessive under-employment and public sector inefficiency, this could be considered a positive outcome. However, one would hope that the private sector is then picking up the slack. Even taking into account the recognition by the Federal Bureau of Statistics that they had been understating unemployment rates prior to 1990-91, the increase in unemployment rates by occupational categories from 1987-88 to 1990-91, and indeed 1993-94 are dramatic, particularly in occupations where one would expect a high incidence of poor workers. At the same time, the wages of skilled and unskilled labour have drastically declined.

One would expect an increase in inequality and poverty to accompany high unemployment rates and declining real wages and that is indeed what occurred. Between 1987-88 and 1990-91, inequality and poverty both increased notably. Apart from unemployment, cuts in subsidies and increases in prices of commodities that are a big component of the consumption pattern of the poor account for this phenomenon. Finally, while the reliance on indirect taxes decreased over 1987-88 to 1990-91 and while the indirect tax structure in Pakistan was mildly progressive in the

${ }^{17}$ Economic Survey 1995-96, Statistical Appendix (1996, p. 137). 
16 The Lahore Journal of Economics, Vol.2, No.1

base year, the incidence of indirect taxes on the poorest tax group increased during this period by 10.4 per cent while that on the richest tax bracket declined by 4.3 per cent.

Our research shows that structural adjustment conditionalities are proving to be detrimental for the socio-economic well being of the poor. We recommend that the government pay close attention to the effects of these policies on employment and on the consumption pattern of the poor. The Social Action Plan, which seeks to build human capital of the rural poor, may be a reasonable long run solution. However, in the short and medium term, the job and nutritional needs of the poor need to be directly addressed through well run patronage free programmes. 
Shahrukh Rafi Khan \& Safiya Aftab 17

\section{References}

eds. Banuri, T., S.R. Khan and M. Mahmood, 1997, Just Development: Protecting the Vulnerable and Promoting Growth, (Karachi: Oxford University Press), forthcoming.

Bilquese, F., 1992. "Trends in Intersectoral Wages in Pakistan: 1977-1990," Eighth Annual General Meeting of the Pakistan Society of Development Economists, Pakistan Institute of Development Economics, Islamabad.

Chaudhry, M. G., and G. M. Chaudhry, 1992. "Trends in Rural Employment and Wages in Pakistan," Eighth Annual General Meeting of the Pakistan Society of Development Economists, Pakistan Institute of Development Economics, Islamabad.

Ender, G., A. Wasay and A. Mahmood, 1992. "Wheat Price Policies in Pakistan: Should There be a Subsidy?" The Pakistan Development Review, Vo1. 31, No. 4.

Government of Pakistan, Federal Bureau of Statistics, 1987-88. Household Income and Expenditure Survey.

Government of Pakistan, Federal Bureau of Statics, 1990-91. Household Income and Expenditure Survey.

Government of Pakistan, Economic Advisors Wind, Pakistan Economic Survey.

Gazdar, H. e1. a1., 1994. "Poverty in Pakistan: Measurement, Trends, and Patterns," prepared for the World Bank, mimeo.

Huntington, S. P., 1993. "The Clash of Civilizations,” Foreign Affairs Vol. 72, No. 3, July - Aug, 1993.

Kemal, A. R., 1994. "Structural Adjustment, Employment, Income Distribution and Poverty", Paper presented at the Tenth Annual General Meeting of the Pakistan Society of Development Economists, PIDE.

Kema1, A. R., and M. Mahmood, "Poverty and Policy in Pakistan", in Just Development, forthcoming. 
18 The Lahore Journal of Economics, Vol.2, No.1

Khan, S. R., S. Kazmi and Z. Ahmed, 1996. "Structural Adjustment and Food Security in Pakistan”, Proceedings of a Conference on Newer Forms of Insecurities in South Asia, Regional Center of Strategic Studies, Sri Lanka, forthcoming.

Malik, et. a1., nd, "Rural Poverty in Pakistan," Paper prepared for the Asian Development Bank, Manila, Mimeo.

Malik, S. J., and N. S. Malik, 1992. "Reporting on the World Nutrition Situation: A Case Study of Pakistan (1976 to 1991)”, Report prepared for the ACC/SCN of the UN.

Sustainable Development Policy Institute, 1995. Nature, Power, People: Citizen's Report on Sustainable Development, Islamabad. 